\title{
適応性をもった純慣性系の最短時間制御
}

\author{
上野 敏 行 \\ 東京大学宇宙航空研究所 東京都目黑区駒場 4-6-1 \\ (昭和 44 年 12 月 24 日 受付)
}

\section{Adaptive Time Optimum Control of a Purely Inertial System}

\author{
Toshiyuki Ueno \\ (Institute of Space and Aeronautical Science, University of Tokyo, Megro-ku, Tokyo)
}

(Received December 24, 1969)

This paper describes a purely inertial system whose attitude around its axis is controlled with air jet, and gives the results of the adaptive optimum control of the system. It is well known that the time optimum control of the purely inertial system can be accomplished by appling positive and negative maximum torques according to the parabolic switching curve in the phase plane. In order to realize the desired switching curve, a nonlinear resistor, called the "varistor", is used in the control system. Keeping the time optimum control loop closed, the small perturbation signal is applied to the system and the inertial moment of the controlled subject is measured by the correlation method. The measured moment is fed into the adaptive control system to determine the optimum switching curve in the phase plane automatically. By changing the moment, it is experimentally verified that the switching curve is optimally set.

The response of the moment measuring system to the sudden change of the moment is described. Also the effects of the test signal on the time optimum control and on the error of the measured moment are stated.

\section{1. まえがき}

純慣性系の最短時間制御問題は，位相面上で放物線 を組み合わせた切換線を設定し，最大操作量を用いて オンオフ制御をすればよいことはよく知られている。

乙か乙実際に位相面の切換線を作ることや，慣性や操 作量などのパラメータ変化に対しての問題ばあまり取 り披われていない。

また，動特性測定はプロセス解析の手段として1つ の独立した問題であるが，適応制御への応用を考光た 問題とすることもできる。そこで本論文ではパラメー 夕の変化する系の動特性測定を行ない，つ权に最適な 制御が実現されるように位相面の切換線を変化させる 系を構成し, 関連する動特性測定の問題, 括よび最適 制御の問題について論じた.

\section{2. 純慣性系の最短時間制御}

空間停止中の VTOL 機（垂直離着陛機）や人工
衛星の一軸采わりの姿勢制御を考えると，制御対象は 純慣性系とみなせる。㐫る姿勢から最短時間で別の姿 勢に向きをか光る制御をしたいとする。そ文のようなあ る目標值に最短時間で到達する系は最適制御のうちで も最短時間制御といわれている。

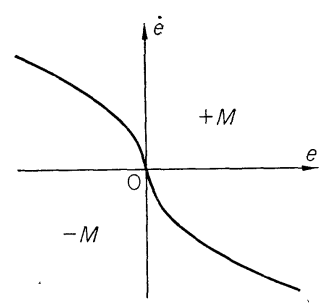

Fig. 1 Switching curve in the phase plane
機体の回転軸まわり の慣性モーメントをJ, 最大操作トルクを $|M|$, 姿勢を示す角度を $c(t)$ とする. 目標值 $r(t)$ のステップ入力に対し て最短時間制御系を作 るには，誤差信号 $e(t)$, $e(t)=r(t)-c(t)$

そついて位相面で Fig. 1 のような切換線を作る。系 の状態がこの切換線のどちらの領域にあるかによって 
土Mの操作をすればよい。このとき系の方程式は

(2) 式となる.

$$
J \frac{d^{2}}{d t^{2}} c(t)= \pm M
$$

Fig. 1 の切換線の方程式は,

$$
e+\frac{J}{2 M} \dot{e}|\dot{e}|=0
$$

である. 切換線を求めることは可能であってもとれを 実現することは一般に簡単ではないのは，他の最適制 御についても同様である. 純慣性系の最短時間制御に ついても, 関数発生器あるいは非線形素子を必要とす るため，実際の装置について実験が試みられたことは 少ない。しかしバリスタと呼ばれる非線形抵抗素子と 演算增幅器を組み合わせると，（3）式の切換線を容易 に実現できる.

バリスタ（シリコンカーバイドバリスタ）は，スイ ッチ回路などの火花消去用としても用いられているが， その特性は最短時間制御系を実現するのに都合のよい 性質を持っている1). 素子の両端の電圧を $E$ ，電流を $I$ とすれば特性は近似的に次のように表わされる。

$$
I=K E^{n}
$$

素子のらちで $n \fallingdotseq 2$ となるものを選び出すことができ るが，める電圧，電流の範囲で，

$$
I=K_{v} \cdot E|E|
$$

と表わせる. 一方向の電流については 2 乗特性を持つ ものは他にもあるが，このように両方向について 2 乗 特性を持つのがこの素子の特徴である. Fig. 2 に使 用した素子の特性を示す．この素子を Fig. 3 のよら に演算増幅器の入力素子として用い, 出力のポテンシ ヨメータの分圧比をにとすれば,

$$
E_{2}=-k\left(K_{v} R_{f}\right) E_{1}\left|E_{1}\right|
$$

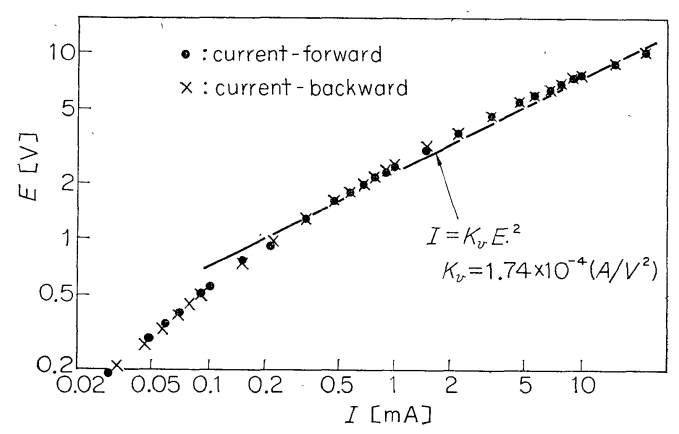

Fig. 2 Voltage-current characteristics of the varistor

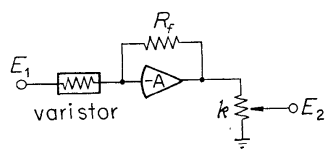

Fig. 3 Operational amplifier using a varistor as an input impedance
となり， $k, R_{f}$ を適当に選ぶことにより切換線を設定 することができる，kを変えれば容易に切換線を変光 られるので, 慣性モーメントが変化したときに切換線 を最適になるよらに変化させていくことができる，最 短時間制御系のブロック図は Fig. 4 のよらになる.

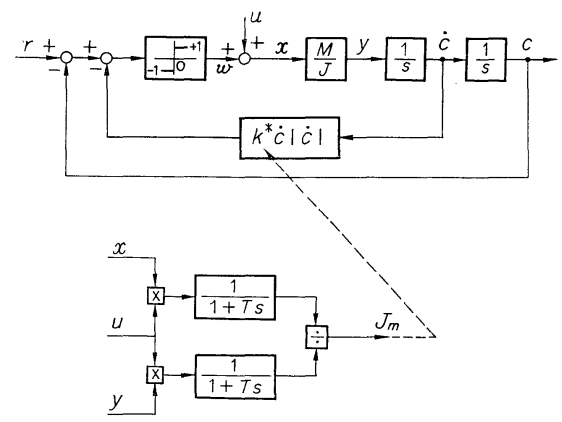

Fig. 4 Block diagram of the time optimum control system and measurement of the inertial moment

Fig. 4 で最適切換線を実現する $k^{*}$ の值 $k_{\mathrm{opt}} *$ は (7) 式となる。

$$
k_{\mathrm{opt}} *=\frac{J}{2 M}
$$

ところが慣性モーメントJは変化するものと考学ら れる．場合によっては $M$ も変化するであろう．ただし 操作量 $M$ の変化は相対的に $J$ の変化とみなせるので, 以下ではJの変化として考えていくことにする. この よらな変化に対応するためには，Jを測りそれに適し た切換線を設定していかねばならない，慣性モーメン トの変化に対して切換線を変化させないと, 目標值の 変化に対してオーバシュートを生じたり，操作量がチ ヤッタリングを起こし動作時間がよけいにかかったり することになる．したがって慣性モーメントの変化を 知るために，制御ループが閉じたままの状態で，制御 対象の動特性測定（この場合には慣性モーメントの測 定）を行なう必要がある。

\section{3. 慣性モーメントの測定と切換線の設定}

動作中のプロセスの動特性を測定する方法は，いろ いろ考觉られている. しかし，ここで必要なのは制御 対象のパラメータの変化であり，それができるだけ簡 単に求められることが望ましい。 また, 制御ループ内 にめるプロセスの動特性測定に，一般の測定法をその ままあてはめるには問題がある。閉ループ内プロセス の動特性を測定するう法の 1 つに，外部からテネトシ グナルを加え，相関法によって SN 比よく動特性測定 を行なら方法がある ${ }^{2), 3)}$. ここではその相関法を用い 
た方法を応用して，慣性モーメントを測ることにする。

Fig. 4 飞和いて系の出力信号として加速度 $y(t)$ を とる. 操作量 $x(t)$ との間には,

$$
y(t)=\frac{M}{J} x(t)+n(t)
$$

の関係がある. $n(t)$ は加速度信号に加わる雑音であ る. nとは独立なテストシグナル $u$ を外部から加え， $x, y$ との積の平均を計算し， $J_{m}$ として $(9)$ 式のよ らに定める.

$$
J_{m}(t)=\frac{\frac{1}{T_{0}} \int_{t-T_{0}}^{t} x\left(t^{\prime}\right) \cdot u\left(t^{\prime}\right) d t^{\prime}}{\frac{1}{T_{0}} \int_{t-T_{0}}^{t} y\left(t^{\prime}\right) \cdot u\left(t^{\prime}\right) d t^{\prime}}
$$

(8) 式から（10）式の関係を導くことができ，

$$
\begin{aligned}
& \frac{1}{T_{0}} \int_{t-T_{0}}^{t} y(t) u(t) d t=\left(\frac{M}{J}\right) \frac{1}{T_{0}} \int_{t-T_{0}}^{t} x(t) u(t) d t \\
& \quad+\frac{1}{T_{0}} \int_{t-T_{0} .}^{t} n(t) u(t) d t
\end{aligned}
$$

十分大きな $T_{0}$ そついては (10) 式の右辺の第 2 項は 小さくなると考㝋られるので，（9）式は,

$$
J_{m}(t) \fallingdotseq \frac{J}{M}
$$

となり，慣性モーメント $J$ を測ることができる。

Fig. 4 に測定系のブロック図を示した. $T_{0}$ 時間の 平均化は 1 次フィルタで行なわれている. Fig. 4 の ブロック図で $k_{\mathrm{opt}}{ }^{*}=J / 2 M$ であるから，測定した $J_{m}$ に比例して最短時間制御装置のポテンショメータの分 圧比 $k$ を設定すれば，Jの変化に対応してつねと $k$ * を最適值 $k_{\mathrm{opt}}$ * に保つことができる. 測定值 $J_{m}$ に 対応してポテンショメータを設定するのにここでは自 動平衡計器の平衡電動機を利用した．ポテンショメー タのかわりに掛算器などを用いれば，電気的に切換線 を変えることも可能である.

本論文の方式では慣性モーメントの測定値 $J_{m}$ に応 じて分圧比 $k$ が設定され，切換線が決められてしまう。 その設定に批いて最短時間制御が実現されているか否 かのフィードバックは行なわれていない、そこがこの 適応系の欠点であるが，逆に，目標値の変化に対し最 短時間応答をする用意がつね杴なされているとるい光 るであるう。

\section{4. アナログ計算機によるシミュレーション}

最短時間制御系の動作を確かめ, 動特性測定装置に よって切換線が正しく設定されることを調べるために 慣性系をアナログ計算機の積分器で置き換えて, シミ ュレーション実験を行なった．制御括よび動特性測定 装置は後で述べる空気ジェットを用いた姿勢制御系に 使用する装置をほとんぞそのまま用いた。
切換線をきめる Fig. 3 の $k$ の值は Fig. 4 の $k_{\mathrm{opt}}$ *

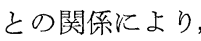

$$
k_{\mathrm{opt}}=\frac{k_{\mathrm{opt}} *}{K_{v} R_{f}}=\frac{J}{2 M K_{v} R_{f}}
$$

となる. 各パラメータの值を代入して求めた $k_{\mathrm{opt}}$ の 值と，実験的に最適となるような值とはよく一致した。 その結果，ここで製作されたバリスタを用いて切換線 を作った装置で，最短時間制御系が実現されることが 確認された.

次にテストシグナルを加えて動特性測定を行ない, それにより最適切換線が設定されることを確かめた。 テストシグナルは簡単に発生できるので $m$ 系列信号 を使用した，そのクロック周波数は $10 \mathrm{~Hz}$ 以下につい て，テストシグナルと操作量の大きさの比は $0.1,0.2$, 平均化フィルタの時定数 $T \fallingdotseq 100,50 \mathrm{~s}$ として, それ らの組み合わせについて調べた。 その結果, アナログ 計算機でのシミュレーション実験では外乱がほとんど ない状態なので, 平均化時定数は小さくてよく, テス トシグナルの $m$ 系列信号のクロック周波数は比較的高 い周波数のものを加えることが可能であり, 発生器の

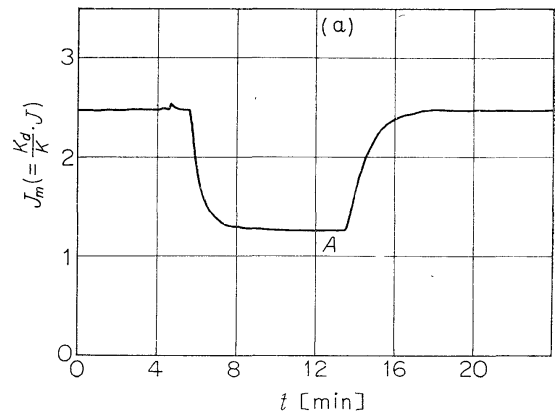

(a) record of the measured inertial moment, $J$ was changed from $J=2$ to 1 , and 1 to 2

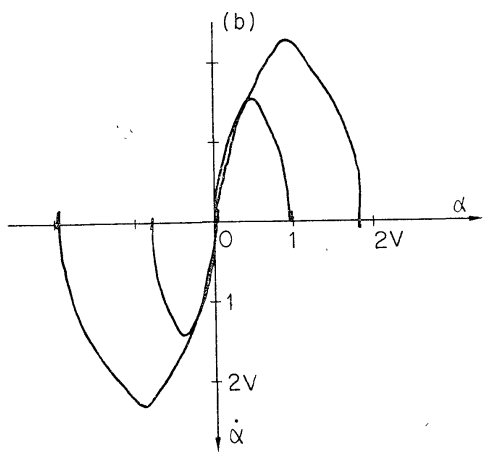

(b) phase plane trajectories at time $A$

Fig. 5 Analog computer simulation $|u| /|w|=0.1$, $T=50 \mathrm{~s}$, clock freq. $=4 \mathrm{~Hz}$ 


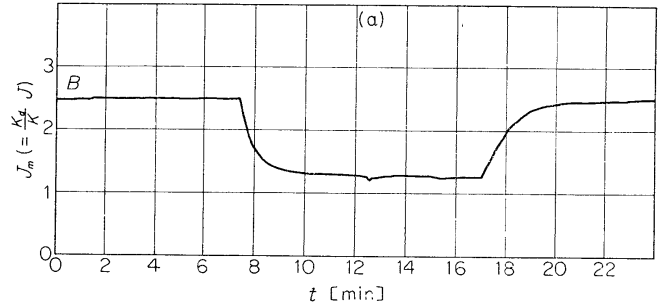

(a) record of the measured inertial moment, $J$ was changed from $J=2$ to 1 , and 1 to 2

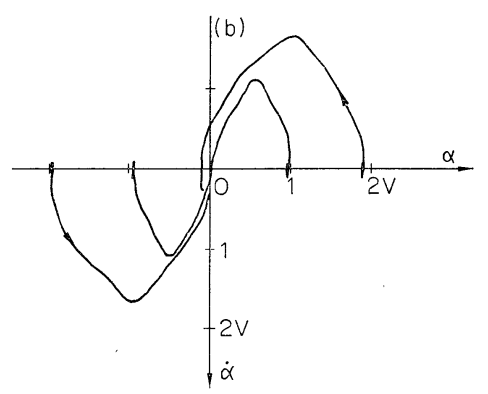

(b) phase plane trajectories at time $B$

Fig. 6 Analog computer simulation $(|u| /|w|=0.2$, $T=100 \mathrm{~s}$, clock freq. $=4 \mathrm{~Hz}$ )

シフトレジスタの段数は測定系に対して影響がないこ とがわかった．テストシグナルと操作信号の大きさの 比が 0.1 であれば十分に慣性モーメントの測定を行な い切換線設定がでさ，最適の最短時間制御をあまり乱 さないが，比が 0.2 亿なると位相面軌跡を乱すように なることが明らかになった。 Fig. 5， Fig. 6 飞測定 例を示した。

\section{5. 空気ジェット姿勢制御系の最短時間制御}

動特性測定により, 制御対象の特性の变化汇適応す ることができ，つね水最短時間制御が実現できること をアナログ計算機による実験だけでなくななる゙く実 物に近い装置で実験を行ない示すのがこの章の目的で ある.制御対象は，圧縮空気を吹き出しその反動によ り一軸のまわりの傾きを制御する機体で岕る。

\section{$5 \cdot 1$ 装置の構成}

純粋な慣性系を想定しているためまさつの少ない支 持方法で，かつ動力源の空気を送る必要がある. Fig. 7 (a) 飞示したように軸は固定され，ベアリングで軸 をとりまく外側の直方体を支える，この直方体の部分 が軸のまわりで回転するが，その上には Fig. 7 (b)の ようにはりと移動和もり, 電磁バルブなどが取り付け られて, バルブの先の下向きのノズルから空気が吹き 出され機体の傾きが変えられる. 支持軸の一方から中

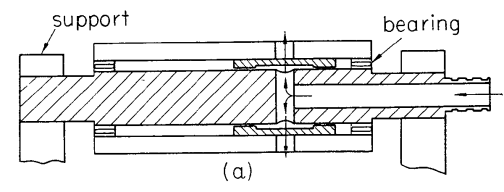

(a) sectinal view of the air supply system

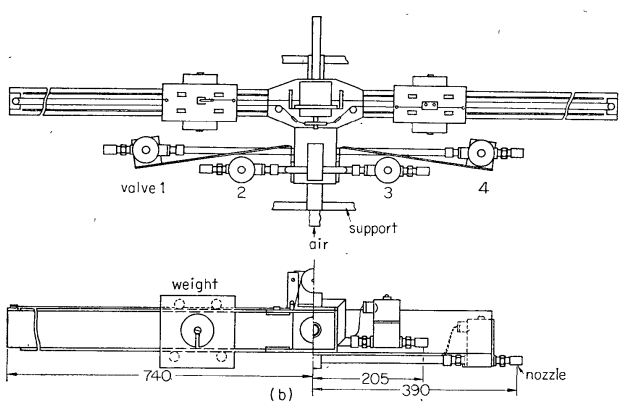

(b) ficture of the attitude control system

Fig. 7

心に穴を通し, 空気はこの穴を通って軸の中注どに垂 直にあけられた穴に達する.この穴の両側では, 直方体 と軸の間は 5/100 mm と狭くしてあるので，空気は汪 とんど大部分回転体に導かれる。慣性モーメントを変 化させるにははりの上の括もり（片側で $1.4 \mathrm{kgr}$ )を 平衡電動機と䒺の機構により，平衡を保ちながら同じ 距離だけ軸に近づけたり遠ざけたりする。な牧，回転 機体全体の重量は $14 \mathrm{kgr}$ である. 空気源の圧力は 3 $\mathrm{kg} / \mathrm{cm}^{2}$ (ゲージ) である.

\section{$5 \cdot 2$ 制御および動特性測定装置}

最短時間制御系と慣性モーメシト測定系のブロック 図を Fig. 8 に示す。ここで注意すべきことは，制御 対象の系の入力信号 $x$ のトルクを直接知ることはでき ないので，電磁バルブの開閉に従い，その絶対值ふわ からなくとも，一定のあらかじめ大きさの比が決まっ たトルクが発生するものとして，バルブ開閉の信号で トルク $x$ に比例する信号 $x_{0}$ を作っている.

角加速度の信号は角速度を微分して $y_{0}$ としている. 微分器の時定数は $1 \mathrm{~ms}$ で, テストシグナルのクロッ ク周期 $(0.25 \mathrm{~s})$ と比べて十分小さく，慣性モーメン 卜測定值への影響は無視することができる.

最短時間制御をするための操作量としてのトルクは, ノズル $1 ， 4$ により $|M|$ のトルクを発生する．テス トシグナルを系に入れるにはノズル $2 ， 3$ (それぞれ 対応するバルブの先のノズル）により $|\varepsilon M|$ の大きさ のトルクを発生させている.

Fig. 9 に回路図の一部を示した. 回転機体の傾き 角を検出するには低トルクのポテンショメータを使用 


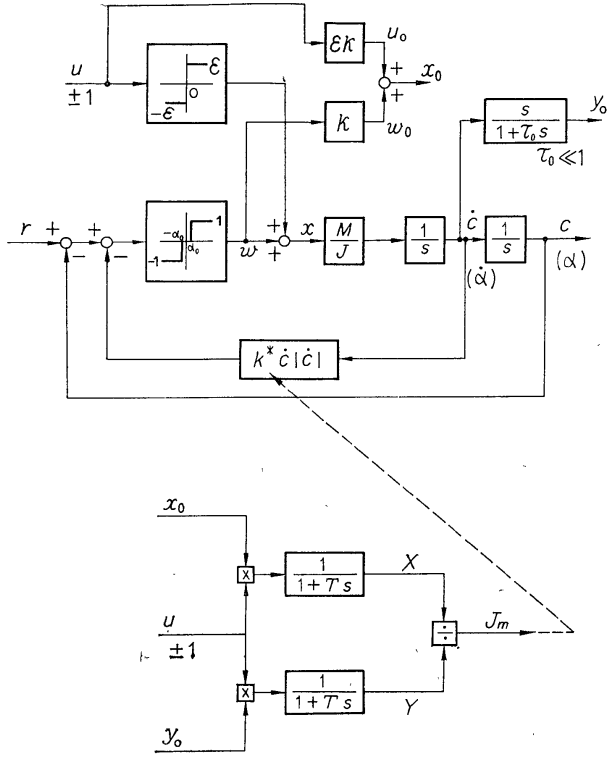

Fig. 8 Block diagram of the adaptive time optimum control system

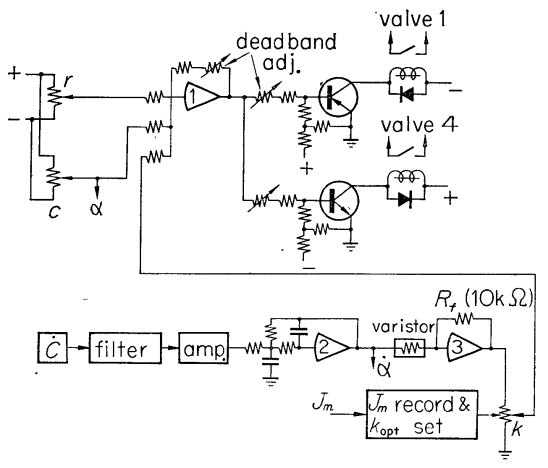

Fig. 9 Diagram of the time optimum control system using a varistor

した. 角度 $c$ 飞対する電圧 $\alpha$ は,

$$
\alpha=K_{\alpha} c \quad K_{\alpha}=3.44[\mathrm{~V} / \mathrm{rad}]
$$

一様な磁界の内でコイルが動けばその速度に比例した 電压が発生する，そこで角速度を測るにはマイクロア ンメータの指針を機体につないで動かしている。途中 のフィルタやアンプを含めた係数は,

$$
\dot{\alpha}=K_{\omega} \dot{c} \quad K_{\omega}=4.15[\mathrm{~V} / \mathrm{rad} / \mathrm{s}]
$$

テストシグナル $u$ との掛算は $u$ が 2 值信号であるので リレーの切換えで行なわれている. また, 割算器はホ ール素子を利用した掛算器を演算増幅器のフィードバ ック回路に組み入れたものである.

\section{$\mathbf{5} \cdot \mathbf{3}$ 動作の記録と解析}

主な質量の, 回転軸の中心からの距離をもとにして あらかじめ計算により軸まわりの慣性モーメントの大
略値を求めると,

$$
\left.\begin{array}{l}
J_{\min }=7.11 \times 10^{6}\left[\mathrm{gr} \cdot \mathrm{cm}^{2}\right] \\
J_{\max }=17.1 \times 10^{6}\left[\mathrm{gr} \cdot \mathrm{cm}^{2}\right]
\end{array}\right\}
$$

と約 2.4 倍変化することになる.

操作信号 $w$ とテスト信号 $u$ にり $M$ と $\varepsilon M$ のトルク を発生させる.トルクの比が $\varepsilon(=0.2)$ になるように ノズルの大きさを推力の計算式 ${ }^{4)}$ によって求めた.

上ざらばかりを用いてトルクを測定してみると,

$$
M / g=5.07 \times 10^{3}[\mathrm{gr} \cdot \mathrm{cm}]
$$

$\varepsilon M / g=1.09 \times 10^{3}[\mathrm{gr} \cdot \mathrm{cm}](\mathrm{g}:$ 重力の加速度) 希望ど特り $\varepsilon=0.2$ とみなすことができる.

最適切換線は角度 $c$, 角速度 $\dot{c}$ について,

$$
c+\frac{J}{2 M} \dot{M}|\dot{c}|=0
$$

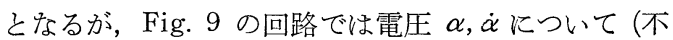
感帯を無視する),

$$
\alpha+k\left(R_{f} K_{v}\right) \dot{\alpha}|\dot{\alpha}|=0
$$

となる. したがって; 上の $M, J$ に対してのポテン ショメータの設定值 $k$ の最適值 $k_{\mathrm{opt}}$ は,

$$
k_{\mathrm{opt}}=\frac{J \cdot K_{\alpha}}{2 M \cdot K_{\omega}^{2} R_{f} K_{v}}
$$

$(15),(16)$ 式の $M, J$ を代入すると $k_{\mathrm{opt}}=0.08\left(J_{\mathrm{min}}\right)$, $k_{\mathrm{opt}}=0.19\left(J_{\max }\right)$ となる. 実験により求めた最適の $k$ は $k_{\mathrm{opt}}=0.11\left(J_{\mathrm{min}}\right), k_{\mathrm{opt}}=0.21\left(J_{\max }\right)$ であった. 慣性モーメントの見積りはごく捇和ざっぱな值であっ たからこの程度の誤差はやむをえず，最短時間制御系 の設計法としては以上に述べたことで十分役立つと思 われる。

Fig. 10, Fig. 11 に $J_{\min }, J_{\max }$ のときに目標値 を $r=r_{0}$ から $r=0$ にステップ状に変化させたときの 位相面軌跡を示した. この位相面の記録から， $J_{\max }$ の軌跡の上の任意の点 $\left(\alpha_{\max }, \dot{\alpha}_{\max }\right), J_{\min }$ の軌跡 の上の任意の点 $\left(\alpha_{\min }, \dot{\alpha}_{\min }\right)$ を読み取ることによ b,

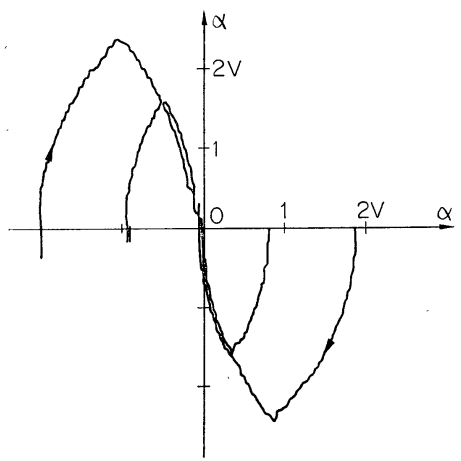

Fig. 10 Phase plane trajectories, $J_{\min }$, test signal is not applied to the system 


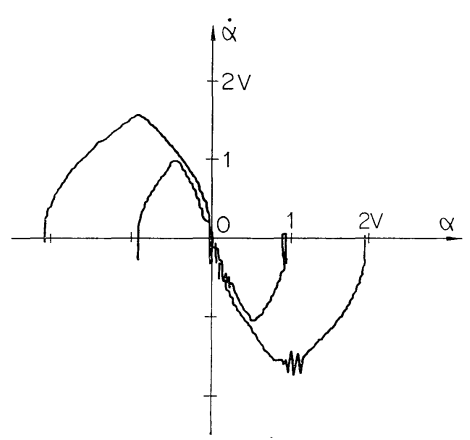

Fig. 11 Phase plane trajectories, $J_{\max }$, test signal is not appleid to the system

$$
\frac{J_{\max }}{J_{\min }}=\frac{\alpha_{\max } / \dot{\alpha}_{\max }{ }^{2}}{\alpha_{\min } / \dot{\alpha}_{\min }{ }^{2}}
$$

として， $J_{\max } / J_{\min }$ を求めることがでさる. Fig. 10, Fig. 11 と (20) 式によれば $J_{\max } / J_{\min }=1.95$ とな る. $k_{\text {opt }}$ の值の比が $0.21 / 0.11=1.91\left(=J_{\max } / J_{\min }\right)$ であることを考光，両方の平均をとると，慣性モーメ ントは実際には 1.93 倍変化していることになる.

$\mathbf{3 \cdot 5 \cdot 1}$ 不感帯 本装置では操作量の正負が切換 わるときに, バルブ開閉の振動が速度検出器に雑音と してはいり，誤動作の原因となる，そこで位相面の原 点付近にだけでなく，切換線にそって Fig. 12 のよ らな不感帯を設けている. 不感帯の大きさは実験的に きめられたが，その大きさは角度にして $2 c_{0}=1.3^{\circ} \sim$ 1.6 6 である.

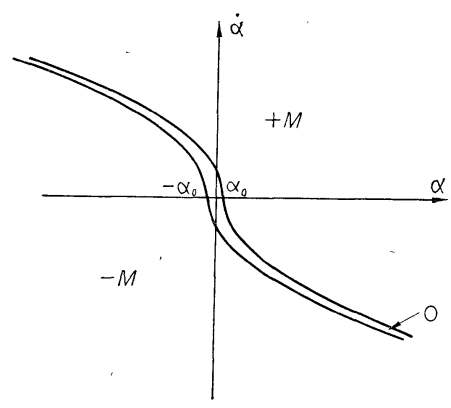

Fig. 12 Switching curve with deadband

$3 \cdot 5 \cdot 2$ テストシグナル・アナログ計算機での実 験で, 発生器のシフトレジスタの段階は測定に影響し ないことがわかっているので，5段のシフトレジスタ の発生する $m$ 系列信号を用いた．末さつのような外乱 や，信号検出回路の㧧くれを考えれば， $m$ 系列のクロ ック周波数は低いほうがよい.いっぽら，テストシグ ナルは制御系にとっては外乱であり, クロック周波数 が高いほらが角速度や角度の外乱としては小さいこと になる.けっきょく、実験的には数 $\mathrm{Hz}$ 程度が適当で，
$4 \mathrm{~Hz}$ としている. アナログ計算機の実験では，テス トシグナルの大きさは操作量の $0.1 / 1$ にしても十分測 定できたが，空気ジェット系ではそれでは測定值が不 安定で, テストシグナルの大きさは操作量の $0.2 / 1$ と している.

$\mathbf{3 \cdot 5 \cdot 3}$ 切換線の自動設定 テストシグナルを加 えて，慣性モーメントを測定しながら $J_{\min }$ から $J_{\max }, J_{\max }$ から $J_{\min }$ と慣性モーメントJをステッ プ状に変化させて 測定値 $J_{m}$ を記録する. それぞれ Fig. 13 (a)，Fig. 14（a）参照. $J_{m}$ が安定したと 思われる所で目標值を変化させ，姿勎制御系の応答を 位相面で記録する. Fig. 13 (b), (c), Fig. 14(b), (c) 参照. このときの平均化フィルタの時定数は 200

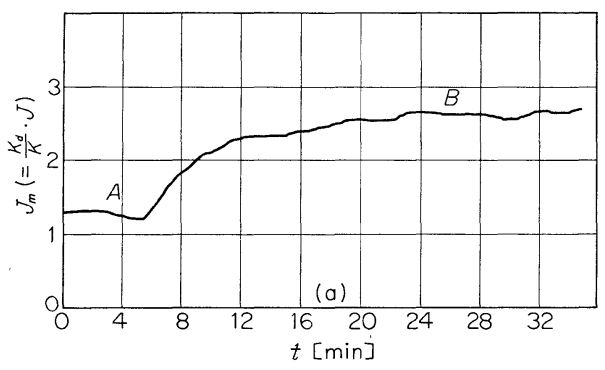

(a) record of the measured inertial moment

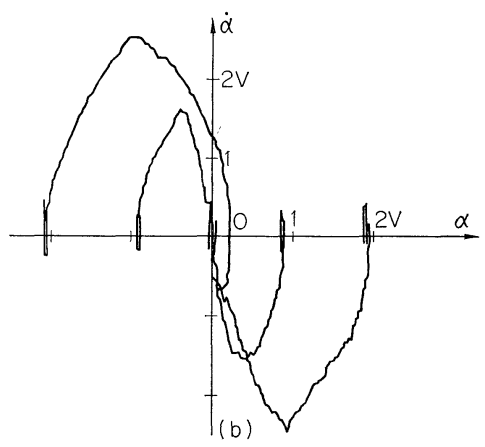

(b) phase plane trajectories at time $A, J_{\min }$

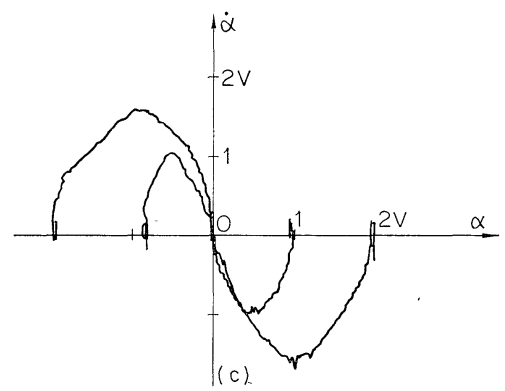

(c) phase plane trajectories at time $B, J_{\max }$

Fig. 13 Air jet control system 


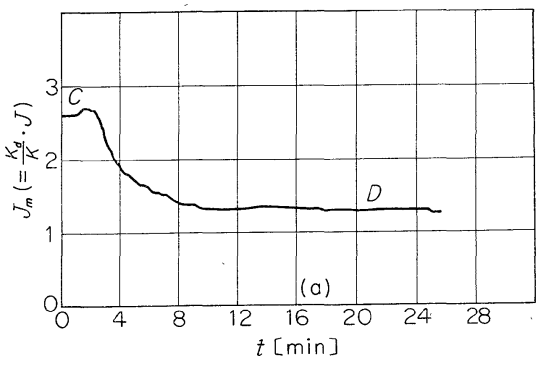

(a) record of the measured inertial moment

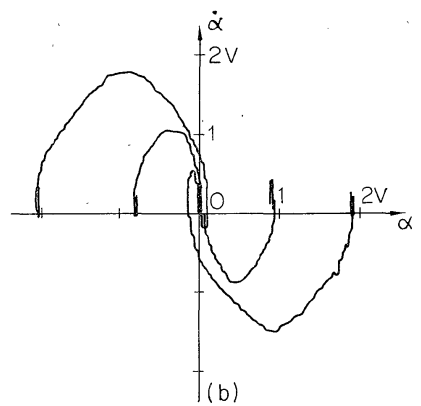

(b) phase plane trajectories at time $c, J_{\max }$

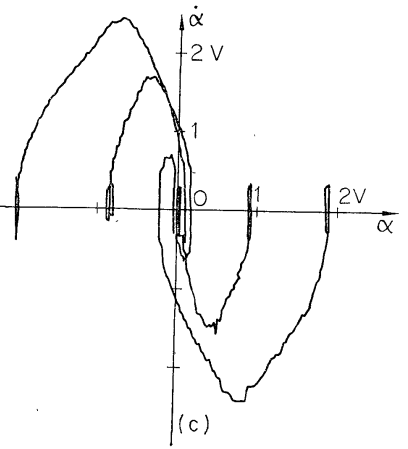

(c) phase plane trajectories at time $D, J_{\min }$

Fig. 14 Air jet control system

sである．慣性モーメントが変化したのに対応して切 換線が変化し，位相面の記録から最短時間制御が行な われていることがわかる．テストシグナルが比較的大 きいので軌跡が乱れるが，この程度はアナログ計算機 でのシミュレーションでも見られたと特りである。

テストシグナルを入れているので回転機体は目標值 飞達したのち, 約 $\pm 0.5^{\circ} \sim 0.8^{\circ}$ ゆれている. これは だいたい不感带の範囲ぐらいで，この制御系の制御成 績は目標值に対して $\pm 1^{\circ}$ 以内とい光よう.

Fig. 13，14の $J_{m}$ の記録によると $J_{\max } / J_{\min }=$ $2.0 \pm 0.1$ となり, あらかじめ求めた $J_{\max } / J_{\min }=$ 1.93 之比較し, 慣性モーメントが正しく測られてい るとい学る， $J_{\min }$ と $J_{\max }$ の間の值についても同様
に慣性モーメントの測定が行なわれ切換線が設定され る.

$3 \cdot 5 \cdot 4$ 慣性モーメント測定值の誤差電磁バル ブ開閉による機体の細かい振動が角速度検出器にはい り，加速度信号 $y_{0}$ には雑音 $n_{0}$ が加わっている，そ の雑音は定常不規則信号とはいえないが，いち特らそ れを仮定し，平均值が 0 で自己相関関数 $\phi_{n n}$ が，

$$
\phi_{n n}(\tau)=\sigma_{n}^{2} e^{-a|\tau|} \cos 2 \pi f_{0} \tau
$$

として招く，このとき測定值 $J_{m}$ の分散を求めると,

$$
\sigma^{2}\left(J_{m}\right) \fallingdotseq\left(K_{d} \frac{J}{K}\right)^{2} c^{2} \cdot \frac{1}{\sigma_{n}^{2}} \int_{0}^{\infty} \phi_{n n}(\tau) d \tau
$$

ただし， $K_{d}$ は割算器の係数， $K$ は加速度信号検出器 の係数である。また， $c$ は $n_{0}$ と $y_{0}$ の振幅の比とし て振動の記録から求めることができる.

$$
c=\frac{E\left[\left|n_{0}\right|\right]}{E\left[\left|y_{0}\right|\right]} \text { あるいは } \frac{\sqrt{E\left[n_{0}^{2}\right]}}{\sqrt{E\left[y_{0}^{2}\right]}}
$$

加速度信号の記録をみて， $a ， f_{0}$ のだいたいの值を求 めると， $a=2.5 \mathrm{~s}^{-1}, f_{0}=25 \mathrm{~Hz}, c$ は高々 5 程度であ る. $T=200 \mathrm{~s}$ にしてあるから，

$$
\sigma\left(J_{m}\right)=\left(K_{d} \frac{J}{K}\right) \times 3 \times 10^{-3}
$$

となる. $\left(K_{d} \frac{J}{K}\right)$ が測定值 $J_{m}$ として記録紙上に記録 されているわ汗であるから，バルブ開閉による雑音を 始めに仮定したようにみなすかぎりに和いては，測定 值 $J_{m}$ に与える影響は微小であるとい方る。

したがって，ここで問題になるのは軸受け付近の特 性であると思われるが，軸受けのまさつを正確に表わ すことはもずかしい，回転機体の傾き具合で,値が変わ るが静止まさつトルクとして約 $100 \mathrm{gr} \cdot \mathrm{cm}$ 泀どはある。 慣性モーメントを変える扮るりは糸で動かされている が，左右の止まる位置が $1 \mathrm{~mm}$ ずれてもる約 $140 \mathrm{gr}$. $\mathrm{cm}$ の不平衡トルクを発生する。 これに対してテスト シグナルを入れる空気ジェットの発生するトルクは約 $1000 \mathrm{gr} \cdot \mathrm{cm}$ である. 慣性モーメント $J$ が大きいとき は，テストシグナルによって機体はゆっくりかつ小さ くゆれ，Jが小さくなれば速くゆれるよらになる。そ のため，まさつなどの影響を一概論ずることはでき ないが，上のような原因で測定值 $J_{m}$ が $10 \%$ 程度ば らつくのはやむを壳ないであろう，T=200 $\mathrm{s}$ と大き くしているのはこのようなまさつなどの影響をできる だけ打消すためである。

3.5.5 測定値 $\boldsymbol{J}_{m}$ のステップ応答 ，慣性をステ ップ状に変化させたときの $J_{m}$ の応答は, 動特性測定 系の動特性を示している，本論文で用いたような動特 性測定系の応答は一般に平均化フィルタの時定数でき まるといわれているが，その内容をもら少しくわしく 
調べてみる.

Fig. 8 のブロック図で $J_{m}$ は $t \geq 0$ に扔いて,

$$
\begin{aligned}
J_{m}(t) & =K_{d} \frac{X(t)}{Y(t)} \\
= & \frac{X_{0} e^{-t / T}+\frac{1}{T} \int_{0}^{t} e^{-\xi / T} u_{x}(t-\xi) d \xi}{Y_{0} e^{-t / T}+\frac{1}{T} \int_{0}^{t} e^{-\xi / T} u_{y}(t-\xi) d \xi}
\end{aligned}
$$

ただし， $X_{0}, Y_{0}$ は $t=0$ での $X(t), Y(t)$ の值, $u_{x}(t)$ $=u(t) \times x_{0}(t), u_{y}(t)=u(t) \times y_{0}(t)$ である. $J_{m}(t)$ が 一定の值に落着くまでは，目標值を变えるようなこと をしないとすれば， $X(t)$ の値はあまり変化しない。 そこで $u_{x}(t)=X_{0}$ とみなし，外乱を無視すれば $y_{0}(t)$ $=\frac{K}{J} x_{0}(t)$ であるので,

$$
u_{y}(t)=u(t) \times y_{0}(t)=\frac{K}{J} u_{x}(t)=\frac{K}{J} X_{0}
$$

また， $t<0$ では $J_{0}$ であったものが $t=0$ で $J$ に変え られたとすれば, $Y_{0}$ を $Y_{0}=\frac{K}{J_{0}} X_{0}$ として和く. 式は,

$$
J_{m}(t)=\frac{K_{d}}{\frac{K}{J_{0}} X_{0}\left\{e^{-t / T}+\frac{J_{0}}{J}\left(1-e^{-t / T}\right)\right\}}
$$

$t=0$ では $J_{m}(0)=K_{d} \frac{J_{0}}{K X_{0}}, t \rightarrow \infty$ では $J_{m}(\infty)=$ $K_{d} \cdot \frac{J}{K X_{0}}$ となる. $J / J_{0}$ を $(1 / 2,2) ，(1 / 4,4)$ と変光 たときの $J_{m}(t)$ を Fig. 15 に示した. Fig. 13, 14
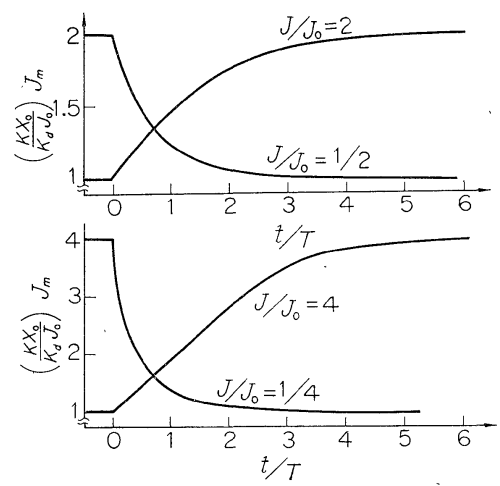

Fig. 15 Response of the moment measuring system to the change of the moment

で $J$ をきくしたときには，測定系の応答が 1 次フィ ルタの応答より䋆そく，Jを小さくしたときは，応答 が速くなっていることは以上のようにして説明される. これは測定対象が大きくステップ状に変化したときの
応答であり， $J_{0} \rightarrow J_{0}+\Delta J$ と微小の変化をしたときに は (27) 式から,

$$
J_{m}(t) \fallingdotseq \frac{K_{d}}{\frac{K}{J_{0}} X_{0}}\left\{1+\frac{\Delta J}{J_{0}}\left(1-e^{-t / T}\right)\right\}
$$

となり，たしかに時定数 た $1 / J_{m}(t)=K_{d} Y(t) / X(t)$ を測定するのであれば (27) 式より応答は 1 次フィルタの時定数 $T$ できめら れる.ただ，ここの実験で $K_{d} X / Y$ を求めているのは 装置の構成が簡単になるためである.

\section{6. む す び}

圧縮空気を動力源とした一軸まわりの姿勢制御系を 製作し, 最短時間で傾きを目標值に修正する系を構成 した. 非線形抵抗素子と演算増幅器およびポテンショ メータにより望みの位相面切換線が実現できることを 示した. 制御対象である純慣性系の慣性モーメントが 変化した場合には, それに応じて位相面切換線を変化 させるよらに，制御系にはつねに小さなテストシグナ ルが加えられ，慣性モーメントが測定されている。そ の測定は姿勢制御のループを切り離すことなく行なわ れている. 約 2 倍の慣性モーメントの変化に対して切 換線を自動的に設定することがでさた．とれにより本 論文で述べたような方法で制御対象の特性が変化して も，つねに最適な制御系を作ることができることを実 験的に確かめられた.

慣性モーメントが変化したときの動特性測定系の応 答，扣よびアナログ計算機でのシミュレーションでは あまり問題にならなかったテストシグナルについても, 空気ジェット系に特忷る動特性測定の誤差との関係が 調べられた。

最後に日ごろ御指導いただく東京大学宇宙航空研究 所五十嵐寿一教授, 石井 泰助教授に感謝の意を表し ます。また，回転機体の軸受け部分の製作に御援助い ただいた，日本レギュレーター（株）取締役川元修三 氏 (現在, 工学院大学工学部) に感謝します.

\section{参 若 文 献}

1）石井 泰・小林健三 :オンオフ式速応サーボ系の解析 と設計, 第 5 回計測自動制御学会学術講演会予稿集, 367/372 (1966)

2）上野敏行：モーメント法によるプロセス動特性の測定， 計測自動制御学会論交集，5-3，265/272（1969）

3） B. B.ソロドフニコフ，A.C. ウスコフ：自動制御系の 統計的解析法, p. 99 (1963-コロナ社)

4）可動アイアンバードの構造执よび機能，航空宇宙技術 研究所資料，TM-71 (1965) 